\title{
PERJANJIAN KERJA SAMA (JOINT VENTURE) PENANAMAN MODAL ASING DALAM USAHA PERHOTELAN
}

\section{Gusti Ngurah Rendra Suryana, I Nyoman Putu Budiartha, Ni Made Puspasutari Ujianti}

Fakultas IImu Hukum Universitas Warmadewa, Denpasar - Bali, Indonesia

\begin{abstract}
Abstrak
Terbentuknya aktivitas investasi di suatu negara sangat bervariasi sesuai dengan sifat keterbukaan dari negara dan masyarakatnya. Oleh karena itu, tercipta dan terjalinnya suatu kerja sama di antara kedua belah pihak disebabkan oleh keinginan untuk mencari keuntungan sehingga sekelompok orang atau beberapa pihak bersama-sama mewujudkan satu perusahaan, baik dengan pihak satu negara maupun lintas Negara. Hal inilah yang membentuk perjanjian joint venture. Berdasarkan latar belakang tersebut, penelitian ini dilakukan dengan tujuan mendeskripsikan bagaimana prosedur pembuatan perjanjian joint venture dalam usaha perhotelan dan apa akibat hukum terhadap wanprestasi perjanjian joint venture dalam usaha perhotelan. Penelitian ini dilakukan dengan menggunakan metode penelitian hukum normatif. Hasil penelitian ini menunjukkan bahwa prosedur pembuatan perjanjian joint venture dalam usaha perhotelan wajib berbentuk perseroan terbatas dan wajib memiliki syarat-syarat dalam mendirikan sebuah perusahaan hotel serta diwajibkan mengajukan izin yang prinsip dan izin usaha tetap yang ditujukan kepada badan kordinasi penanam modal guna menyampaikan laporan kegiatan penanam modal. Selain itu, akibat hukum terhadap wanprestasi perjanjian joint venture dalam usaha perhotelan adalah bagi mereka yang melanggar perjanjian tersebut, pihak-pihak yang bersangkutan terkait perjanjian, akan dikenakan sanksi peraturan perundang-undangan terkait aturan perjanjian joint venture maupun peraturan yang telah mereka sepakati bersama.
\end{abstract}

Kata Kunci: Penanaman Modal; Perjanjian kerja sama; Usaha Perhotelan

\begin{abstract}
The formation of investment activities in a country varies greatly according to the open nature of the country and its people. Therefore, cooperation is created and established between the two parties is because of the desire to seek profit so that a group of people together create a company, either with parties from one country or across countries. This is what forms a joint venture agreement. Based on this background, this research was conducted with the aim of describing how the procedure for making a joint venture agreement in the hotel business and what the legal consequences are for the default of the joint venture agreement in the hotel business. This research was conducted using a normative legal research method. The results of this study indicated that the procedure for making a joint venture agreement in a hotel business must be in the form of a limited liability company and must have conditions in providing a hotel company and are required to apply for a principle license and a permanent business license subject to the investor coordinating body to submit reports on the investor's activities. In addition, the legal consequence of the joint venture agreement default in the hospitality business is that those who violate the agreement, the parties related to the agreement, will be subject to statutory sanctions related to the rules of the joint venture agreement as well as the regulations that they have agreed upon together.
\end{abstract}

Keywords: Investment; Cooperation Agreement; Hospitality Business

\section{PENDAHULUAN}

Terbentuknya kegiatan investasi pada suatu negara sangat bervariasi. Dengan terdapatnya sifat terbuka untuk umum dari negara dengan warga negaranya ataupun dengan negara lain akan menciptakan suatu kerja sama yang sifatnya ingin mencari keuntungan dari kedua belah pihak (Makhfudz, 2016; Salami, 2011; Zakaria, Santosa, Ganta, \& Anjani, 2017). Maka dari itu, beberapa pihak atau orang-orang mempunyai keinginan atau berniat dengan bersama-sama membangun atau mendirikan suatu perusahaan dengan pihak yang ada di dalam maupun pihak luar negeri. Sudah sangat biasa kita lihat perusahaan berpatungan dengan pemegang sahamnya yang berasal dari 
berbagai negara yang ada di dunia pada era globalisasi sekarang ini. Indonesia merupakan negara yang memiliki karakteristik tersendiri dengan keunikan yang membuat wisatawan tertarik untuk mengunjunginya. Salah satu ketertarikan lokal yang yang menarik perhatian wisatawan adalah Provinsi. Keunikan dan daya tariknya dapat dirasakan dari berbagai keindahan dari alamnya, beberapa pusat wisata, dan kebudayaanya sendiri, sehingga munculnya PMA (penanam modal asing) juga menimbulkan keinginan penanam modal asing untuk menanamkan modalnya ke dalam suatu negara untuk melakukan kerja sama. Oleh karena itu, terbentuklah perjanjian kerja sama (Joint venture). Awal mula investasi meliputi berbagai bidang termasuk kepariwisatan bahwa kekuatan pariwisata Indonesia terletak pada potesi alam yang luar biasa luas dan seni budaya yang berbagai macam, sumber daya manusia yang profesional, penginapan perhotelan yang baik, dan masyarakat yang ramah (Sembiring, 2010).

Bisnis usaha pariwisata yang digemari oleh para investor asing dalam hal menanamkan modalnya yakni usaha perhotelan (Budiastuti, Andri, \& Agus, 2010; Julianti \& Subekti, 2018). Perhotelan merupakan kegiatan penyedian jasa dalam bentuk penginapan. Investasi asing sampai saat ini merupakan faktor yang penting untuk menjalankan dan mengembangkan pertumbuhan ekonomi. Harapan masuknya investasi asing dalam faktanya masih susah untuk diciptakan. Faktor yang dapat mempengaruhi Penanam modal asing dalam menanamkan modalnya, antara lain: faktor sumber daya alam, faktor sumber daya manusia, faktor stabilitas politik dan perekonomian guna menjamin kepastian dalam berusaha. Di era globalisasi seperti sekarang sangat mustahil bahwa suatu negara tidak melakukan kerja sama dalam bentuk joint venture mengingat adanya hal untuk saling membutuhkan dan saling melengkapi dalam sebuah urusan negara yang biasanya identik dengan permasalahan perekonomian. Dengan didirikanya perusahan joint venture, diharapkan akan mempermudah dalam hal pemodalan, pembiayaan dan juga perekonomian, pemasaran produk ataupun memperlancar proyek yang didirikan.

Investasi asing diatur dalam UUPM. Adanya investasi asing diharapkan untuk masa mendatang tidak untuk memajukan industri ke arah modern melainkan dapat meningkatkan pendapatan negara, pemerintah daerah, pertumbuhan ekonomi, perluasan atau memperbanyak dalam bidang lapangan kerja, pengetahuan dan juga teknologi (Udiana, 2011).

Penelitian terdahulu yang berkaitan dengan penelitian ini berjudul 'Penanaman Modal dan Permasalahannya di Indonesia' yang dilakukan oleh Hursepuny (2019). Penelitian terkait lainnya dilakukan oleh Yusrizal (2018) dengan tujuan penelitian membahas bagaimana peran notaris dalam mendorong terciptanya kepastian hukum bagi investor dalam investasi asing dengan tujuan untuk mengetahui sejauh mana peran notaris dalam melayani investor asing. Selain itu, Sukananda dan Mudiparwanto (2019) melakukan penelitian yang juga berkaitan dengan penelitian ini. Penelitian mereka bertujuan untuk menganalisa secara mendalam mengenai peraturan penanaman modal asing berbentuk perusahaan Joint Venture di Indonesia serta kendala yang dihadapi dalam pelaksanaan Joint Venture di Indonesia.

Berdasarkan latar belakang yang telah diuraikan di atas, penelitian ini dilakukan dengan tujuan mendeskripsikan bagaimana prosedur pembuatan perjanjian joint venture dalam usaha perhotelan dan apa akibat hukum terhadap wanprestasi perjanjian joint venture dalam usaha perhotelan.

\section{METODE PENELITIAN}

Penelitian ini didesain dengan menggunakan metode penelitian hukum normatif. Penelitian ini merupakan penelitian hukum yang dikonsepkan dengan apa yang tertulis dari aturan perundangundangan maupun norma yang menjadi pedoman dalam berperilaku dalam bermasyarakat. Oleh karena itu, pendekatan penelitian yang digunakan adalah pendekatan Perundang-Undangan. Sumber data penelitian ini adalah bahan hukum primer dan bahan hukum sekunder. Data dikumpulkan dengan menggunakan metode kajian pustaka. Data yang sudah terkumpul kemudian dianalisis menggunakan metode kualitatif dan disajikan secara deksriptif.

\section{HASIL DAN PEMBAHASAN}

\section{Prosedur Pembuatan Perjanjian Joint venture dalam Usaha Perhotelan}

Perjanjian merupakan suatu kesepakatan yang mana perbuatan-perbuatannya berkaitan dengan wanprestasi atau akibat hukum. Perjanjian tersebut juga bisa dikatakan sebagai perbuatan untuk mendapatkan seperangkat hak dan kewajiban. Perbuatan hukum dalam perjanjian merupakan 
perbuatan-perbuatan untuk melakukan sesuatu, yaitu mendapatkan seperangkat hak dan kewajiban yang disebut pencapaian.

Perjanjian kerja sama yaitu suatu perbuatan di mana satu pihak ataupun lebih mengikatkan dirinya terhadap sebuah kontrak dengan satu orang atau lebih. Perjanjian adalah suatu terjadinya peristiwa di mana seseorang berjanji kepada orang atau pihak lain di mana dua orang itu sepakat untuk melaksanakan sesuatu hal untuk mencapai kesepakatan dalam sebuah perjanjian. Melalui ikatan yang sudah ada dengan terlaksananya ikatan atau hubungan terciptalah ikatan. Dalam setiap ikatan diharuskan bahwa posisi masing-masing pihak pembuat perjanjian adalah sama, baik dalam hal kemampuan ataupun pengetahuan masing-masing pihak tentang isi perjanjian. Akan tetapi, dalam faktanya sering terjadi dalam pembentukan sebuah perjanjian salah satu pihak memiliki kedudukan yang lebih kuat dibandingkan pihak yang lain. Ini menimbulkan pihak yang tidak kuat hanya mempumyai dua pilihan, yaitu menerima begitu saja syarat dan prosedur yang diserahkan oleh pihak yang lebih kuat kedudukanya atau tidak menerimanya.

Kebebasan berkontrak adalah hal penting dalam suatu kontrak. Kedua belah pihak boleh mengadakan perjanjian apapun meski belum di atur dalam KUHperdata, namun kebebasan ini juga ada batasnya. Oleh karena itu, ada beberapa prosedur atau syarat dalam joint venture yaitu:

1. Wajib berbentuk Perseroan Terbatas jika memiliki unsur modal asing.

2. Bagi joint venture Penanam modal asing, modal dalam negeri minimal $51 \%$ dari modal perusahan patungan tersebut. Namun kepemilikan ini bisa lebih besar atau lebih kecil, tergantung pada bidang usaha yang akan dimasuki oleh perusahaan joint venture tersebut mengingat Pemerintah Indonesia telah menerbitkan list Negatif Investasi yang di dalamnya disebutkan maksimal modal asing yang boleh masuk pada bidang usaha tertentu. Untuk lebih jelas bidang usaha, dapat dilihat pada, list Bidang Usaha Yang privasi atau Bidang Usaha Yang umum Dengan ketentuann di Bidang Penanam Modal.

3. Ada beberapa bidang usaha yang privasi untuk perusahaan patungan modal sehingga calon investor harus mengecek dulu list Negatif Investasi yang terbaru.

4. Perusahan Patungan Modal Penanam modal asing harus mengajukan izin prinsip ataupun izin usaha tetap ke Badan Kordinasi Penanaman Modal.

5. Perusahann patungan modal Penanam modal asing secara menerus menyampaikan Laporan Kegiatan Penanaman Modal.

Pada dasarnya, berakhirnya kontrak kerja sama Join Venture dapat dilakukan dengan beberapa cara, yaitu:

1. Masing-masing pihak sepakat dan setuju untuk mengakhiri kerja sama sebelum jangka waktu berakhir.

2. Terjadinya wanprestasi oleh salah satu pihak yang dapat menimbulkan pemutusan kerja sama.

3. Jangka waktu kontrak kerja sama telah berakhir.

Syarat prosedur untuk mengikat modal asing, yaitu:

1. Prosedur keuntungan ekonomi

Adanya peluang ekonomi untuk investor, yakni dekat dengan sumber daya alam, tersedianya lokasi tempat untuk mendirikan bangunan, dan tersedianya tenaga kerja.

2. Kepastian hukum

Pemerintah diwajibkan mampu menegakkan hukum terkait sangketa ataupun masalah hukum di masa mendatang guna memberikan jaminan keamanan. Jadi, itu adalah suatu prosedur yang sangat penting dalam rangka menarik investor.

3. Ketentuan stabiltas politik

Penanam modal asing pada sebuah negara dipengaruhi pada faktor stabilitas politik. Masalah yang terjadi pada warganegara akan berpengaruh terhadap iklim penanaman modal.

Dalam perjanjian joint venture antara pihak modal asing dalam negeri maupun pemilik saham modal asing tidak diperlukan untuk membentuk perusahaan baru. Dengan kata lain perusahaan itu dapat bergabung dengan perusahaan lain dan membentuk suatu perusahaan.

Patungan modal atau joint venture adalah sebuah struktur perjanjian dengan dua pihak perusahan atau lebih yang bertujuan sama. Perjanjian tersebut tidak dibedakaan antara joint venture sebagai penanam modal asing maupun penanam modal dalam negeri. Joint venture diputuskan oleh pemilik modal asing dikarenakan kekhawatiran adanya pengambilalihan secara semena-mena tanpa melewati prosedur hukum dari negara penerimaa modal. Namun secara hukum, nasionalisasi, joint 
venture dijadikan sebagai salah satu model aktivitas investasi penanam modal yang diterapkan oleh penanam modal asing sebai investor melaui perusahan patungan modal yang melaksanakan usahanya di wilayah Indonesia.

Penyusunan perjanjian joint ventre yaitu langkah utama dalam menciptakan perusahaan. Joint venture berisikan persetujuan dari para pihak dalam hal kepemilikan modal, kepemilikan saham, keuangan, kepengurusan, teknologi, tenaga ahli, penyelesaian permasalahan sangketa yang akan terjadi dikemudian hari, dan berakhirnya perjanjian. Bagi penanam modal asing yang ingin menanamkan modalnya di bidang perhotelan terdapat syarat serta mekanisme yang harus dipatuhi oleh penanam modal, yakni penanam modal yang berkeinginan menanamkan modalnya harus memenuhi prosedur ketentuan maupun syarat-syarat agar bisa melaksanakan penanaman modal di bidang perhotelan.

Peraturan perundang-undangan tentang kontrak joint venture antara lain:

1. UU Nomor 25 Tahun 2007 tentang Penanama Modal.

2. PP Nomor 17 tahun 1992 Peraturan Pemerintah Nomor 7 Tahun 1993 tentang Pemilikan Saham Perusahaan Penanam Modal Asing

3. Aturan Pemerintah No 20 Tahun 1994 tentang Kepemilikan Saham dalam Perusahaan yang Didirikan dalam Struktur Penanaman Modal Asing

4. Surat Keputusan Menteri Negara Penggerak dana Investasi atau Ketua Badan Kordinasi Penanaman Modal, tentang Prosedur Pelaksanan Kepemilikan Saham dalam Perusahaan yang Didirikan dalam Rancangan Penanama Modal Asing.

\section{Akibat Hukum terhadap Wanprestasi Perjanjian Joint Venture dalam Usaha Perhotelan}

Setiap permasalahan hukum yang terjadi pada bidang penanaman modal asing, asal mulanya dapat dituntaskan oleh lembaga penyelesaian sangketa, lembaga arbitrase. Salah satu penyelesaian sangketa yaitu Arbitrase. Adapun jenisnya, yakni baik Arbitrase Nasional ataupun Arbitrase Internasional. Lembaga Arbitrase Internasional yang meyelesaikan sangketa ataupun permasalahan penanam modal asing, yaitu ICSID, namun tidak menjamin permasalahan yang terjadi dapat dibawa pada lembaga penyelesaian sangketa, klausula Arbitrase yang telah disetujui oleh masing-masing pihak. Hubungan perjanjian joint venture pihak asing selalu mewajibkan adanya klausula Arbitrase. Contohnya dalam hubungan perjanjian masing-masing pihak telah sepakat dan setuju untuk membuat klausula Arbitrase yang tunduk pada aturan ICSID. Oleh karena itu, masing-masing pihak sangat mengharapkan agar penyelesaian yang terjadi suatu hari nanti dalam perjanjian penanam modal dapat di selesaikan melalui ICSID.

Adapun lembaga yang telah dipaparkan di atas, masih banyak pula lembaga Arbitrase baik yang sifat nasional ataupun Internasional yang dipunyai setiap negara. Lalu pada penanaman modal juga diterapkannya asas kebebasan. Yang dimaksud dalam hal ini merupakan kebebasan untuk menentukan pilihan hukum.

Pilihan hukum merupakan suatu keadaan di mana masing-masing pihak yang berkaitan pada hubungan perjanjian dalam suatu kontrak bebas untuk melakukan pilihan dalam menyelesaikan sangketa yang timbul. Mereka dapat menentukan pilihan hukum yang dapat digunakan untuk menyelesaikan permasalahan yang ada pada kedua belah pihak terkait perjanjian untuk kontrak. Pilihan hukum yaitu hukum yang telah dipilih oleh masing-masing pihak dalam timbulnya sangketa akibat hukum wanprestasi yang telah diperbuat atau dilanggar.

Berikut ini merupakan beberapa pelanggaran yang mungkin dilanggar oleh Pihak-Pihak Patungan Modal:

1. Tidak melakukan pembinaan terhadap Pihak Pertama baik atas usaha operasional, manajemen ataupun keuangan yang dibiayai dengan modal patungan tersebut.

2. Pihak Pertama tidak menyetorkan modal yang telah disetujui dan disepakati pada perjanjian joint venture tentang Kepemilikan Saham Perusahaan Penanam Modal Asing

3. Pihak Pertama tidak mengembalikan modal yang telah diterima kepada Pihak Kedua dalam jangka waktu 10 tahun seperti yang telah disepakati dalam perjanjian patungan modal. Di kenakan denda dari total nilai modal yang disetorkan untuk keterlambatan setiap harinya. Setelah keterlambatan 50 hari atau denda $10 \%$ dari total nilai modal yang disetorkan. 
4. Tidak menyediakan tanah untuk pembuatan lahan hotel dan tidak mendapatkan tenaga kerja sesuai dengan yang disepakati sebelumnya dalam perjanjian patungan modal akan dikenakan sanksi berupa denda.

5. Pihak Pertama tidak mengurus surat perizinan berusaha kepada Menteri Negara Penggerak dana Investasi. Surat Keputusn Menteri Negara Penggerak dana Investasi/ Ketua Badan Koordinasi Penanaman Modal tentang aturan Penerapan Kepemilikan Saham dalam Perusahaan yang Didirikan dalam Rancangan Penanam Modal Asing.

Beberapa Sanksi dalam Usaha Perhotelan:

1. Setiap Pengusaha Hotel yang tidak memenuhi syarat sebagaimana dimaksud tentang tata cara pendaftaran usaha penyediaan akomodasi yang dikenakan teguran tertulis pertama yang menyatakan "setiap usaha hotel wajib memiliki sertifikat dan memenuhi persyaratan standar usaha hotel".

2. Apabila dalam waktu 40 hari sudah beroperasi sesudah diberikan teguran tertulis pertama Pengusaha Hotel tidak memenuhi syarat sebagaimana dimaksud, Pengusaha Hotel dikenakan teguran tertulis kedua, yaitu sertifikat usaha hotel adalah bukti tertulis yang telah memenuhi standar usaha hotel oleh lembaga sertifikasi usaha pariwisata kepada pengusaha hotel.

3. Apabila dalam waktu 40 hari sudah beroperasi setelah diberikan teguran tertulis kedua, Pengusaha Hotel tidak memenuhi ketentuan sebagaimana dimaksud, pengusaha dikenakan teguran tertulis ketiga, yaitu pembinaan dan pengawasan sanksi administratif.

4. Apabila dalam waktu 40 hari sudah beroperasi sesudah diberikan teguan tertulis ketiga, Pengusaha Hotel tidak memenuhi ketentuan syarat sebagaimana dimaksud yaitu dikenakan sanksi pembatasan kegiatan usaha.

5. Apabila waktu 60 hari sudah beroperasi sesudah dikenakan sanksi pembatasn kegiatan usaha, Pengusahaa Hotel tidak memenuhi ketentuan syarat sebagaimana dimaksud dikenakan sanksi pembekuan usaha.

\section{SIMPULAN DAN SARAN \\ Simpulan}

Prosedur pembuatan perjanjian joint venture dalam usaha perhotelan wajib berbentuk perseroan terbatas dan wajib memiliki syarat-syarat dalam mendirikan sebuah perusahaan hotel serta diwajibkan mengajukan izin yang prinsip dan izin usaha tetap yang ditujukan kepada badan kordinasi penanam modal guna menyampaikan laporan kegiatan penanam modal. Selain itu, akibat hukum terhadap wanprestasi perjanjian joint venture dalam usaha perhotelan adalah bagi mereka yang melanggar perjanjian tersebut, pihak-pihak yang bersangkutan terkait perjanjian, akan dikenakan sanksi peraturan perundang-undangan terkait aturan perjanjian joint venture maupun peraturan yang telah mereka sepakati bersama.

\section{Saran}

Adapun saran yang perlu disampaikan berdasarkan hasil penelitian ini, yaitu: di masa mendatang agar pemerintah memberikan surat izin berusaha lebih mudah dari sebelumnya, sehingga dapat meningkatkan investasi dan meningkatnya penanam modal asing yang baru bagi Negara dan bisa memperluas lapangan kerja baru bagi masyarakat dalam negeri guna mengurangi angka pengangguran dalam negara. Selain itu, pemerintah diharapkan agar menambahkan peraturan-peraturan joint venture yang baru dari sebelumnya yang masih kurang efisien demi kelancaran sebuah perjanjian yang dibuat.

\section{DAFTAR PUSTAKA}

Budiastuti, D., Andri, \& Agus. (2010). Peluang Usaha Industri Pariwisata di Jakarta Selatan. Binus Business Review, 1(2), 425-433.

Hursepuny, J. (2019). Penanaman Modal dan Permasalahannya di Indonesia. JISAMAR (Journal of Information System, Applied, Management, Accounting and Reserach), 3(2), 72-78.

Julianti, L., \& Subekti, R. P. (2018). Standar Perlindungan Hukum Kegiatan Investasi pada Bisnis Jasa Pariwisata di Indonesia. Kerta Wicaksana, 12(2), 156-166.

Makhfudz, M. (2016). Seberapa Penting Investasi Asing Dipertahankan di Indonesia. ADIL: Jurnal Hukum, $7(1), 129-133$. 
Jurnal Konstruksi Hukum

Vol. 1, No. 2, 2020

Salami, R. U. (2011). Hukum Pasar Modal dan Tanggung Jawab Sosial. Jurnal Dinamika Hukum, 11(3), 439449.

Sembiring, S. (2010). Hukum Investasi: Pembahasan Dilengkapi dengan Undang-Undang Nomor 25 Tahun 2007 tentang Penanaman Modal.

Sukananda, S., \& Mudiparwanto, W. A. (2019). Pengaturan Penanaman Modal Asing dalam Bentuk Perusahaan Joint Venture di Indonesia. Diversi Jurnal Hukum, 5(2), 210-236.

Udiana, I. M. (2011). Rekonstruksi Pengaturan Penyelesaian Sengketa Penanaman Modal Asing.

Yusrizal. (2018). Peran Notaris dalam Mendorong Terciptanya Kepastian Hukum bagi Investor dalam Investasi Asing. Jurnal Lex Renaissance, 3(2), 359-376.

Zakaria, H., Santosa, H., Ganta, F. D. M., \& Anjani, R. F. (2017). Pengaruh Hukum dan Politik terhadap Perkembangan Investasi Asing di Indonesia. Serambi Hukum, 10(02), 69-90. 